\title{
An Overview on Lean Application Methods for Produvtivity Improvement
}

\author{
Soham Ravishekhar Deshpande \\ Department of Industrial Engineering, \\ Shri Ramdeobaba College of Engineering and Management, \\ Nagpur, India
}

\begin{abstract}
At the present time, the manufacturing industry is globalized, where the variety, cost, quality and fulfillment of delivery limits are important factors for the consumer. To meet these demands industries must find strategies to make their processes more flexible and efficient. However, organizations face many challenges in terms of increased standard time, lead time, work in process, etc. Many trials are being done to overcome these challenges by using lean tools. To reduce the waste and nonvalue added activities, lean manufacturing techniques are famous for varying their concepts that occur in many industries. The study reviewed some lean tools such as value stream mapping, single minute exchange of dies, overall equipment efficiency, cellular manufacturing, assembly line balancing, Kanban, total productive maintenance, Maynard operation sequence technique. The different strategies discussed here are helpful in deciding the best suitable lean manufacturing tool with low cost and maximum profitability.
\end{abstract}

Keywords-Lean Manufacturing; SMED; VSM; Cellular Manufacturing; MOST; ALB; OEE; Kanban; Total Productive Maintenance

\section{INTRODUCTION}

In the mid 50's, Japanese developed lean philosophy/ lean thinking/ lean manufacturing/ Toyota production system. This concept of lean manufacturing is used worldwide by the firms. Concept of lean was first proposed by Womack et al. [1] which includes different set of tools. Womack and Jones [2] stated due to lean thinking philosophy, moved to new areas such as services, trade and public sector. Among the other areas, this lean philosophy is not aware as enough in the service sectors [3]. In the present competition scenario which is going in the global way, lean manufacturing techniques are the key tools to succeed. Companies are trying to find effectiveness and efficiency through lean appliance [1]. By increasing the value and quality life of product, it can get more efficient. Minimizing internal and external variability, it gets more effective [1, 2]. Researchers reported that beginning in lean application practices with core value adding processes. Most value is added in the shop floor, inputs are converted to productions according to the demand of market [1]. Large amount of different products with low price and high quality using minimal resources can be done through lean manufacturing practices by the minimization of waste [4]. Transportation, inventory, motion waiting, overproduction, over processing and defect are some of the sources for non-value adding activity. Many researchers have studied the lean tools that can be successfully implemented in the company [4-7]. This paper thus focuses on the application of lean tools as well as the latest surveys done which can make a drastic difference in improving productivity. Paper also helps in implementing these practices in an efficient and effective way in an industry.

\section{APPLICATIONS OF LEAN/ LEAN MANUFACTURING TECHNIQUES}

Antonio et al. [8] defined areas of Lean practices: Flexibility, Waste elimination, Optimization, Monitoring of processes and Involvement of people. Lean manufacturing or lean practices is the approach which is inspired by Japanese management methods in particular to Toyota Production Systems which reduces waste and improves productivity by all means [8]. Many case studies were conducted on the application of lean tools and results were published and service called lean service came into existence [9]. It is important to know the important lean manufacturing tools applied by the firms in competitive environment and its advantages. Toyota, as an example of Japanese automobile companies have high lean implementation success rate due to their tenacity in thorough employee management, equipment and resources as identified by [9]. For successful implementing of lean manufacturing there are some tools for application. Value stream mapping (VSM), single minute exchange of die (SMED), overall equipment efficiency (OEE), cellular manufacturing (CM), line balancing (LB), Kanban, and Maynard operation sequence technique (MOST) are some of the lean application tools which are commonly used by the industries. VSM is the process of representing of information and material flows to co-ordinate with the activities performed by the manufacturers, suppliers and distributers to deliver their products and services to the consumer [4]. Set of techniques used for reducing setup time of a machine is represented as SMED [4]. OEE involves set of methods which refers to effectiveness numerical measurement of several pieces of equipment of the productive system [10]. Cellular manufacturing is the set of sub systems decomposed by a system for the improvement of the industry [11]. Assembly Line balancing problem is to arrange the individual processing and assembly tasks at the workstations so that the total time required at each workstation is same. Kanban system is the arrangement of inventory in the company which is the major issue and which can cause in productivity improvement [12]. MOST is a predetermined motion time method which is used for estimating time standards for several operations or sub operations carried out in industry [13]. These are some applications of lean manufacturing which helps in improvisation of productivity. Transformation of the traditional assembly line to a lean one is a good solution to improve efficiency, effectiveness and profitability. 


\section{VALUE STREAM MAPPING (VSM)}

Problem Solving, Physical Transformation, Information management are the three different business management tasks to bring a specific product to all the set of specific actions required is defined by Value Stream. Value Stream Mapping is a lean application tool used in companies for maximization of productivity". Ruther and Shook [14] reported that VSM is the method used to visualize and understand the process of the organization studied and a process where you "Learn to see". Ruther and Shook [14] first developed the method of value stream mapping by giving a view of material flow starting from raw material purchase to product expedition. Further attention is given on eliminating waste, adding value and establishing flow, by looking at the value stream.

As shown in Table 1 Value stream mapping visualizes and streamlines Lean manufacturing by work processes using tools and techniques. In the processes VSM helps to demonstrate, identify and reduce waste. Lean manufacturing is served by VSM as a blue print [15]. To enable economic success at hard times, Lean System tools such as VSM, TPM, OEE, and SMED can be adopted to the journey of world class manufacturing for increasing volatility, global crisis, and sales crisis. Working on adjusting the system's cycle times to follow Takt Time will improve the overall performance [16]. To enhance value, improve flow and eliminate waste, VSM can be used for continued opportunities that constitutes four steps that are identifying the product, create a current state value stream map, create a future state value stream map followed by making action plan. Process cycle efficiency, cycle time, and takt time were calculated for prior and post states for comparison. Result was reduced number of employees, takt time and process cycle time [17]. During demand uncertainty, simulation model is necessary for predicting the inventory level. Future state map is not only capable of predicting the levels throughout the production process as with a static model one cannot observe how inventory levels will vary for different scenarios $[18,19]$.

Table no. 1 Value Stream Mapping

\begin{tabular}{|c|c|c|}
\hline Author & Methodology & Results \\
\hline $\begin{array}{l}\text { Singh et al. } \\
(2018) \text { [20] }\end{array}$ & $\begin{array}{l}\text { Application of VSM } \\
\text { methodology for analysis } \\
\text { and optimization of } \\
\text { manufacturing processes } \\
\text { in MSMEs. }\end{array}$ & $\begin{array}{l}\text { Increase in production of } \\
\text { Swan Mechanical works } \\
\text { by } 42 \%, 36.46 \% \text { for Kotla } \\
\text { auto parts, and } 35.35 \% \text { in } \\
\text { B.S. Spray painting } \\
\text { works. Reduction of work } \\
\text { for Kotla carton box } \\
80.97 \% \text { and } 63.73 \% \text { in } \\
\text { B.S. Spray painting } \\
\text { works. }\end{array}$ \\
\hline $\begin{array}{l}\text { Stadnicka \& } \\
\text { Ratnayake } \\
(2016)[21]\end{array}$ & $\begin{array}{l}\text { For service disturbance } \\
\text { minimization, applying } \\
\text { VSM methodology in } \\
\text { telecommunication } \\
\text { industry. }\end{array}$ & $\begin{array}{l}50 \% \text { reduction in service } \\
\text { lead time, which gives the } \\
\text { capability to deliver } \\
\text { almost double the amount } \\
\text { of installation service. }\end{array}$ \\
\hline $\begin{array}{l}\text { Stadnicka \& } \\
\text { Ratnayake } \\
(2017)[22]\end{array}$ & $\begin{array}{l}\text { Use of VSM methodology } \\
\text { together with other tools, } \\
\text { which were used in aircraft } \\
\text { maintainance services for } \\
\text { miniomization of cost, } \\
\text { lead time and services. }\end{array}$ & $\begin{array}{l}\text { Reduced lead time by } \\
63 \% \text {. Process cycle } \\
\text { efficiency has increased } \\
\text { by about four times. }\end{array}$ \\
\hline $\begin{array}{l}\text { Brown et al. } \\
(2014) \text { [23] }\end{array}$ & $\begin{array}{l}\text { Application case studies of } \\
\text { sustainable VSM } \\
\text { methodology in different }\end{array}$ & $\begin{array}{l}\text { Successful demonstration } \\
\text { of how to approach the } \\
\text { construction } \\
\text { Sustainable VSM in } \\
\end{array}$ \\
\hline
\end{tabular}

\begin{tabular}{|l|l|l|}
\hline & $\begin{array}{l}\text { manufacturing system } \\
\text { configuration. }\end{array}$ & $\begin{array}{l}\text { different production } \\
\text { environment. }\end{array}$ \\
\hline $\begin{array}{l}\text { Espinosa et al. } \\
(2014)[24]\end{array}$ & $\begin{array}{l}\text { A case study based on } \\
\text { methodology for } \\
\text { supporting } \\
\text { implementation based on } \\
\text { the VSM in Latin- } \\
\text { American Multinational } \\
\text { company. }\end{array}$ & $\begin{array}{l}\text { VSM can be used as a } \\
\text { meta language to facilitate } \\
\text { second order learning in } \\
\text { anganization going } \\
\text { through a self- } \\
\text { transformation process. }\end{array}$ \\
\hline
\end{tabular}

IV. SINGLE MINUTE EXCHANGE OF DIE (SMED) Single Minute Exchange of Dies (SMED) is one of the Lean tools used for waste reduction and decreased setup time of a machine in modern industry. SMED methodology is first introduced by Shigeo Shingo [25] which assures a fast and efficient change of running product to the next one. It can reduce the changeover time that is the period between the first finished product coming out from production order and the last finished product from previous production order leaving machine [26, 27]. Advantage is economic production of manufacturing lots, requires low investment in the production process as well as low equipment setup times enabling the management of industrial unit to respond quickly to market demand, also reduces occurrence of errors in the equipment [28]. SMED comprises of four stages, the preliminary stage where the internal and external setup conditions are not distinguished, separating internal and external activities setup takes place in first one, internal activities are converted into external ones in the second one, third stage focuses on streamlining aspects of the setup operations [25]. SMED addresses setups performed by one operator involving one single machine. SMED should also address the manufacturing lines formed by multiple machines and controlled by multiple operators, also a disadvantage that it cannot measure the mean setup time during the changeover in the manufacturing cell [29]. Coimbra E. A. (2009) proposed that the Economic Order Quantity (EOQ) can help to explain the reduction of lot size by SMED technology. Ordering costs and total annual cycleinventory holding is minimized by lot size defined by EOQ as given in Fig 1. Being affected directly by changeovers due to time loses, equipment efficiency is related with ordering costs. Keeping items in hand such as storage, insurance, handling or handling work is related with total inventory costs in a production environment [28].

Rosa et al. [30] carried out SMED methodology at automotive industry and implemented actions targeted to tool types, identification, tool organization, and reorganization of internal and external tasks, detailed setup files, visual aids and operator training and the results were execution of setups to stoppage time on line was reduced by $58.3 \%$ corresponding to 210min. Application of SMED to electron-beam machining in Automotive industry is done to three electron beam machines led to changes in the equipment which produced impact, reducing 50\% of setup time [31]. Sousa et al. [32] implemented SMED methodology in cork stoppers production and an overall analysis is done by applying Value stream mapping and overall equipment efficiency and a $43 \%$ reduction in changeover time is achieved and various other researches carried out shown in Table 2 . 
Table no. 2 Single Minute Exchange of Dies

\begin{tabular}{|l|l|l|}
\hline Author & Methodology & Results \\
\hline $\begin{array}{l}\text { Karam et al. } \\
(2018) \text { [33] }\end{array}$ & $\begin{array}{l}\text { Adapted SMED } \\
\text { methodology to improve } \\
\text { the changeover process } \\
\text { time at bottle filling line } \\
\text { in a pharmaceutical } \\
\text { company. }\end{array}$ & $\begin{array}{l}\text { Implementing SMED by } \\
\text { externalizing steps, visual } \\
\text { management and FTE } \\
\text { redistribution led to 30\% } \\
\text { reduced completion time. }\end{array}$ \\
\hline $\begin{array}{l}\text { Brito et al. } \\
(2017) \text { [34] }\end{array}$ & $\begin{array}{l}\text { Combining SMED } \\
\text { methodology and } \\
\text { Ergonomics for } \\
\text { reduction of changeover } \\
\text { time. }\end{array}$ & $\begin{array}{l}\text { Setup time reduced from } \\
105 \text { minutes to 57 minutes } \\
\text { which meant a reduction of } \\
46 \% .\end{array}$ \\
\hline $\begin{array}{l}\text { Godina et al. } \\
(2018) \text { [35] }\end{array}$ & $\begin{array}{l}\text { Reviewed a structural } \\
\text { literature of SMED. }\end{array}$ & $\begin{array}{l}\text { Most case studies are done } \\
\text { at automotive industry and } \\
\text { gaining focus since 2007. }\end{array}$ \\
\hline $\begin{array}{l}\text { Simoes \& } \\
\text { Tenera (2010) } \\
\text { [36] }\end{array}$ & $\begin{array}{l}\text { SMED applied in a press } \\
\text { line or a tandem line at } \\
\text { automotive industry for } \\
\text { reduction in setup time. }\end{array}$ & $\begin{array}{l}28 \% \text { reduction } \\
\text { changeover time. in }\end{array}$ \\
\hline $\begin{array}{l}\text { Rosa et al. } \\
(2017)[30]\end{array}$ & $\begin{array}{l}\text { SMED methodology } \\
\text { adapted at automotive } \\
\text { industry for reducing the } \\
\text { impact of changeover } \\
\text { time. }\end{array}$ & $\begin{array}{l}\text { Stoppage time reduced to } \\
58 \% .\end{array}$ \\
\hline
\end{tabular}
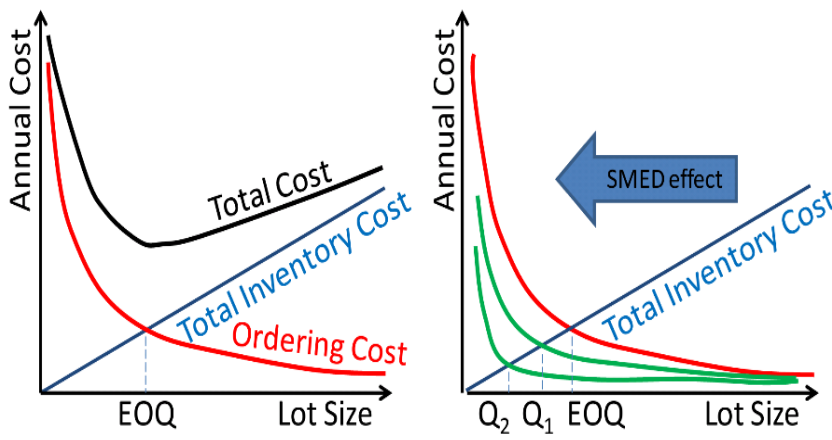

Fig 1 Economic Order Quantity and SMED effect on reducing ordering cost due to change-over time reduction [27].

\section{OVERALL EQUIPMENT EFFICIENCY}

In the 1970's, Overall Equipment Effectiveness (OEE) is introduced in the Japanese Industry, in the context of the Total Productive Maintenance program. As shown in Table 3, Companies use Overall Equipment Effectiveness method for achieving the lean production goals where in specified it is a percentage number that is usually defined by multiplying (which comprises the six big losses divided into three categories shown in Figure 2 ) the availability rate, performance rate and quality rate defined by the equation (1) below. To make constraint or bottleneck equipment to run more efficiently is the main objective to measure OEE. To diagnose the result and then to plan and execute the corrective actions, the purpose was to inform the Maintenance department about the effectiveness of the equipment under consideration [37]. To see where the equipment is losing time OEE and its individual factors will give the plant numbers [38]. Managers can identify the causes of the time losses and attempt to reduce these losses, computation of OEE requires consistent data which reflects the real equipment utilization based on the utilization estimated, [39]. How effectively a manufacturing operation is understood, OEE is a hierarchy of metrics that is measured [40, 41].

$\mathrm{OEE}=(\mathrm{A})$ Availability $\times(\mathrm{P})$ Performance $\times(\mathrm{Q})$ Quality

Nakajima [42] asserted that under ideal conditions, firms should have $\mathrm{Q}>0.99, \mathrm{P}>0.95$ and $\mathrm{A}>0.90$. These figures would result in an OEE $>0.85$ for world-class firms, and Nakajima considers this figure to be a good benchmark for a typical manufacturing capability. Nakajima [42] argues that an OEE under 0.50 is more realistic, taking into account that OEE indicators usually vary between 0.30 and 0.80 . . The performance rate $(\mathrm{P})$ (equation 3 ) indicates the actual deviation in time from the ideal cycle time. Availability (A) (equation 2) measures the total time that the system is not operating due to breakdowns, set-up and adjustment, and other stoppages. The quality rate $(\mathrm{Q})$ (equation 4 ) denotes the relationship between the number of units produced and the number of units produced that meet specifications [10].

(A)Availability $=\frac{\text { Loading time }- \text { Downtime }(\mathrm{h})}{\text { Loading time }(\mathrm{h})} \times 100$

(P)Performance $=\frac{\text { Theoretical cycle time }(\mathrm{h}) \times \text { Actual output }(\text { units })}{\text { Operating time }(\mathrm{h})} \times 100$

(Q)Quality $=\frac{\text { Good parts (units) }}{\text { Total Production (units) }} \times 100$

Table no. 4 Overall Equipment Efficiency

\begin{tabular}{|l|l|l|}
\hline Author & Methodology & Results \\
\hline $\begin{array}{l}\text { Puvanasvaran } \\
\text { (2013) [43] }\end{array}$ & $\begin{array}{l}\text { Applying OEE with } \\
\text { Time study in an } \\
\text { Aerospace industry. }\end{array}$ & $\begin{array}{l}4.64 \% \text { increase in the } \\
\text { availability ratio. This is } \\
\text { due to increase in higher } \\
\text { operating time contributes } \\
\text { in increase in OEE } \\
\text { percentage from 84.32\% to } \\
88.94 \% .\end{array}$ \\
\hline $\begin{array}{l}\text { Hedman et al. } \\
\text { (2016) [44] }\end{array}$ & $\begin{array}{l}\text { Measurement of pitfalls } \\
\text { and identify critical } \\
\text { factors in the OEE } \\
\text { methodology }\end{array}$ & $\begin{array}{l}\text { The recorded performance } \\
\text { rate for 702 out of 884 } \\
\text { machines had the value } \\
100 \% \text { implying that almost } \\
80 \% \text { of the machines were } \\
\text { operating at 100\% } \\
\text { efficiency. }\end{array}$ \\
\hline $\begin{array}{l}\text { Kumar et al. } \\
(2014) \text { [45] }\end{array}$ & $\begin{array}{l}\text { OEE methodology was } \\
\text { carried out to improve } \\
\text { the production planning } \\
\text { and process } \\
\text { improvement in the } \\
\text { impeller manufacturing } \\
\text { industry. }\end{array}$ & $\begin{array}{l}\text { Improved } \\
\text { performance by 4.4\% and } \\
47 \% \text { reduction in the setup } \\
\text { times in impellers. }\end{array}$ \\
\hline
\end{tabular}




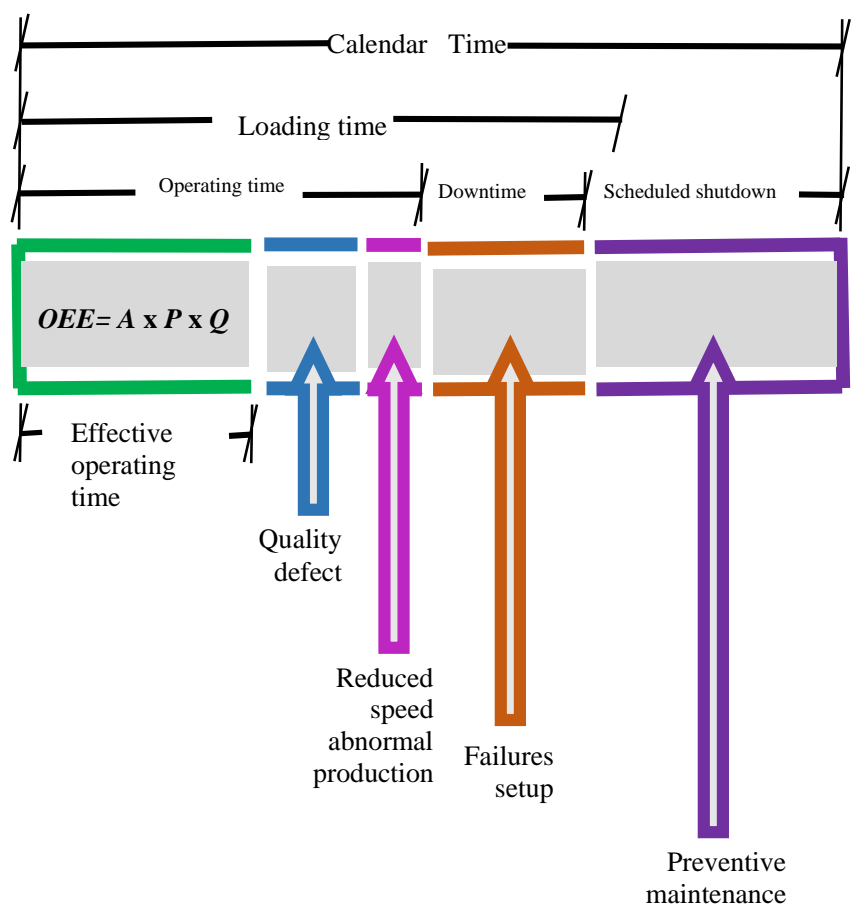

Fig 3. OEE Timeline [42]

\section{CELLULAR MANUFACTURING (CM)}

Cellular manufacturing is developed by Russian called Mitrofanow in the 1940's which is an application of a methodology called group technology [46-49]. To bifurcate a manufacturing system into subsystems in order to improve its efficiency which was the idea behind group technology as described in Table 4 [11]. Methodology based on similarity coefficients in conjunction for the formation of manufacturing cells with clustering procedures [50]. Cellular manufacturing system design that minimizes total system costs and maximizes machine reliabilities along selected processing routes by multi objective mixed integer programming model [51]. Cellular manufacturing reduces cycle time and increases flexibility, based on creating manufacturing cells which can be workstations or machines by combining produced parts or products together into families depending on the required process for the product [52]. Product families which are combined together, the cell layout is based on products, identical machines are kept together in a process layout [53]. The cycle time is equal to the throughput time depending on the degree of overlap of operations in the cell. Overlap is easy to accomplish because machines or processes in cells are very close to each other with cellular manufacturing [53].

Table no. 4 Cellular Manufacturing

\begin{tabular}{|l|l|l|}
\hline Author & Methodology & Results \\
\hline Eliguzel \& \& & Cellular Manufacturing & Distance between \\
Ozceylan & methodology is applied in & machines is decreased \\
(2019) [49] & $\begin{array}{l}\text { the layout of a gym center } \\
\text { for the problem of location } \\
\text { of equipmen for each } \\
\text { program to use it }\end{array}$ & $\begin{array}{l}\text { increase in space } \\
\text { utilization. } \\
\text { efficiently. }\end{array}$ \\
\hline
\end{tabular}

\begin{tabular}{|l|l|l|}
\hline $\begin{array}{l}\text { Gu \& Monid } \\
\text { (1993) [54] }\end{array}$ & $\begin{array}{l}\text { Cellular manufacturing } \\
\text { methodology used as a } \\
\text { clustering algorithm to } \\
\text { design the system. It consist } \\
\text { of two parts: cluster seeking } \\
\text { process and minimization } \\
\text { of bottlenecks. }\end{array}$ & $\begin{array}{l}\text { Algorithm is flexible } \\
\text { and easy to use. All the } \\
\text { working identical cells } \\
\text { are brought together } \\
\text { and the bottleneck is } \\
\text { minimized. }\end{array}$ \\
\hline $\begin{array}{l}\text { Angra et al. } \\
\text { (2008) [11] }\end{array}$ & $\begin{array}{l}\text { Applying tellular } \\
\text { manufacturing ro to } \\
\text { investigate by comparing } \\
\text { the performance of time- } \\
\text { based model with workload } \\
\text { based model. }\end{array}$ & $\begin{array}{l}\text { The time-based model } \\
\text { for even distribution of } \\
\text { workload gives better } \\
\text { results than the } \\
\text { workload based model. } \\
\text { The minimum value of } \\
\text { workload deviation } \\
\text { and deviation index } \\
\text { indicates the good } \\
\text { performance of the cell } \\
\text { formation procedure. }\end{array}$ \\
\hline
\end{tabular}

\section{ASSEMBLY LINE BALANCING}

In order to achieve required run rate, to minimize imbalance among workloads and workers, a technique known as Line Balancing is used [55]. Hence a line should be evaluated in terms of workstations layout, assembly process, and workstation cycle time. In manufacturing industries such as electronics, furniture and textile, assembly line balancing is very popular. The work-in-process smoothly flows through the line with less buffers between steps of assembly process reinforced by lean line balancing as described in Table 5 [55]. In the work for placed production of line balancing problem with work station in series and blocks of parallel operations at the work stations. The operations which are subdivided in blocks and the blocks of same work station were performed simultaneously by one spindle. The operation time of the workstation was the highest value among operation times of its blocks. The line cycle time was the maximal workstation time [56]. Well-organized approach for type II robotic assembly line balancing, in which the assembly tasks had allotted to workstations and each workstation needs to select one of the available robots to process the allocated tasks with the objective of minimum cycle time. An innovative genetic algorithm hybridized with local search was proposed for the problem [56].

Table no. 6 Assembly Line Balancing

\begin{tabular}{|l|l|l|}
\hline Author & Methodology & Results \\
\hline $\begin{array}{l}\text { Fansuri et al. } \\
\text { (2018) [57] }\end{array}$ & $\begin{array}{l}\text { Application lean line } \\
\text { balancing methodology in } \\
\text { an electronic company for } \\
\text { productivity improvement. }\end{array}$ & $\begin{array}{l}\text { Standard time is brought to } \\
\text { proposed level at 39 } \\
\text { seconds by adding one } \\
\text { additional operator to work } \\
\text { station number 2. }\end{array}$ \\
\hline $\begin{array}{l}\text { Lopes et al. } \\
\text { (2017) [58] }\end{array}$ & $\begin{array}{l}\text { The balancing problem of } \\
\text { robotic spot welding } \\
\text { manufacturing lines is } \\
\text { modeled at a car factory on } \\
\text { the outskirts of Curitiba, } \\
\text { Brazil. }\end{array}$ & $\begin{array}{l}\text { Productivity gain achieved } \\
\text { is 6.6\% when compared to } \\
\text { the as-is configurations. }\end{array}$ \\
\hline $\begin{array}{l}\text { Lam et al. } \\
\text { (2016) [55] }\end{array}$ & $\begin{array}{l}\text { Lean line balancing is } \\
\text { carried out for an electronic } \\
\text { assembly line by using } \\
\text { suitable tools such as } \\
\text { multiple activity chart, } \\
\text { ishikawa chart, and activity } \\
\text { analysis table. }\end{array}$ & $\begin{array}{l}\text { Electronics assembly line } \\
\text { was improved in terms of } \\
\text { productivity, elimination of } \\
\text { waste, overall labor } \\
\text { effectiveness, } \\
\text { balancing index. Human } \\
\text { resource was decreased } \\
25 \% .\end{array}$ \\
\hline
\end{tabular}




\section{KANBAN}

Kanban is a Japanese word originated from "Kahn-bahn" when translated it means "visible record". Kanban system is mostly used in the country of Japan as it is originated from this country $[59,60]$. Minimum inventory at one time can be achieved by the implementation of Kanban methodology which is one of the tools of lean manufacturing is reported by researchers as shown in Table 7. Advantages of Kanban, provides managing business and operations in the industry, and reduces waste in production resulting in less lead time [12]. With increase in Kanban size, will accumulate work in process but improve fill rate, on the other hand reducing the Kanban size improves the performance of the system by lowering inventory levels and the make span [61]. Cost model into a two-card Kanban system was introduced by determining the optimal number of Kanban, with a fixed Kanban size. Objective of the algorithm is that it can be employed to reduce the expected cost per period. Certain value of number of Kanban can achieve the lowest average cost by balancing the backlogged inventory and ordering cost [61].

Table no. 7 Kanban

\begin{tabular}{|c|c|c|}
\hline Author & Methodology & Results \\
\hline $\begin{array}{l}\text { Domingos et } \\
\text { al. (2014) [62] }\end{array}$ & $\begin{array}{l}\text { Reduction of losses due } \\
\text { to excess inventory and } \\
\text { unnecessary movement } \\
\text { in the Kanban inventory } \\
\text { in a multinational } \\
\text { industry manufacturer } \\
\text { of machinery and } \\
\text { equipment, located in } \\
\text { the State of São Paulo, } \\
\text { Brazil. }\end{array}$ & $\begin{array}{l}\text { There was a reduction in } \\
\text { the size of the boxes in } \\
13 \% \text { of the items with } \\
\text { approximately } 86 \text { items } \\
\text { from domestic suppliers } \\
\text { and also from imported } \\
\text { parts. }\end{array}$ \\
\hline $\begin{array}{l}\text { Rahman et al. } \\
\text { (2013) [12] }\end{array}$ & $\begin{array}{l}\text { Kanban system } \\
\text { implementation as a } \\
\text { lean manufacturing } \\
\text { tool. }\end{array}$ & $\begin{array}{l}\text { Kanban system was } \\
\text { adequate due to the } \\
\text { benefits such as the } \\
\text { operational costs, wastes, } \\
\text { scraps and losses were } \\
\text { reduced, over production } \\
\text { stocks were controlled } \\
\text { with flexible work } \\
\text { stations. }\end{array}$ \\
\hline $\begin{array}{l}\text { Naufal et al. } \\
(2012) \text { [63] }\end{array}$ & $\begin{array}{l}\text { Industrial case for } \\
\text { applying Kanban in a } \\
\text { manufacturing site. }\end{array}$ & $\begin{array}{l}\text { Kanban system is essential } \\
\text { in ensuring the success of } \\
\text { Just In Time practice and } \\
\text { to create smooth flow of } \\
\text { part throughout } \\
\text { manufacturing system. } \\
\text { Lead time, in-process and } \\
\text { finished goods inventory, } \\
\text { finished good area } \\
\text { improved. }\end{array}$ \\
\hline
\end{tabular}

IX. TOTAL PRODUCTIVE MAINTAINANCE

In Japan, in 1971, the concept of Total Productive Maintenance was presented to solve maintenance problems of systems by giving employees and operators more responsibility [64]. Autonomous, planned and preventive are some of the meanings of the Total productive maintenance which directly connects to machines and facilities. Higher levels of efficiency and effectiveness can be achieved by the total productive maintenance and becomes a basic foundation for operational performance stability and improvements is reported by researchers as shown in Table 8 [65]. It acts as a key tool for production management. Profitability, production technologies, and efficiency can also be achieved through
TPM. Based on standardization of process, repair and maintenance activities should be completed smoothly and easily [66]. Downtimes occurred due to planned or unplanned ways should be minimized. TPM helps companies to support their business by increasing the entire life of the equipment in the good condition and is also relevant to maximize the effectiveness of the equipment, improving in overall efficiency and helping organizations get benefits with the approach of role model comprehensive productive-maintenance model [67]. By the implementation of total productive maintenance every level person is benefitted from top level executive to floor operator, and also helps companies to have a productive and smart preventive maintenance [68]. Total productive maintenance acts as a key pillar, helping organizations to increase their productivity and overall equipment effectiveness. Some of the tasks which are critical such as work descriptions per equipment, equipment spots, specifying tools, visual instruments, training the operator in maintenance, clear definitions for the best sequence of activities, change over and standard work activities are the tasks for the planned maintenance [68]. As shown in the Fig 3, TPM starts with 5S which methodically organize the workplace and working practices and can be broken down into 5 phases named after Japanese words which begins with letter "S" Sort, Straighten, Shine, Standardize, and Sustain, so the $5 \mathrm{~S}$ is given. TPM is among the essential strategies for maintenance policies [69].

Table no. 9 Total Productive Maintenance

\begin{tabular}{|c|c|c|}
\hline Author & Methodology & Results \\
\hline $\begin{array}{l}\text { Sethia et al. } \\
(2014) \text { [68] }\end{array}$ & $\begin{array}{l}\text { Case study based on TPM } \\
\text { methodology carried out } \\
\text { in a rolling mill to study } \\
\text { the manufacturing } \\
\text { process. }\end{array}$ & $\begin{array}{l}\text { The performance of the } \\
\text { Rolling Mill come to be } \\
60.33 \% \text {. The availability } \\
\text { of the line is } 70.90 \% \text { of } \\
\text { the production time. The } \\
\text { performance rate is } \\
91.03 \% \text { while the } \\
\text { quality rate comes to be } \\
93.48 \% \text {. }\end{array}$ \\
\hline $\begin{array}{l}\text { Ngadiman et } \\
\text { al. (2012) [66] }\end{array}$ & $\begin{array}{l}\text { Use of TPM methodology } \\
\text { by experimental study } \\
\text { through instruments used } \\
\text { to collect data are } \\
\text { observation } \\
\text { calculation. }\end{array}$ & $\begin{array}{l}\text { TPM has three (3) main } \\
\text { aims to achieve that are } \\
\text { Zero Product Defects, } \\
\text { Zero Equipment } \\
\text { Unplanned Failure and } \\
\text { Zero Accident. }\end{array}$ \\
\hline $\begin{array}{l}\text { Hegde et al. } \\
(2009) \text { [70] }\end{array}$ & $\begin{array}{l}\text { Application of } \text { TPM } \\
\text { methodology in a } \text { CNC } \\
\text { machine shop. }\end{array}$ & $\begin{array}{l}\text { The TPM approach } \\
\text { showed that the OEE } \\
\text { was improved from } 43 \% \\
\text { to } 72 \% \text { which indicate } \\
\text { the desired level. }\end{array}$ \\
\hline
\end{tabular}




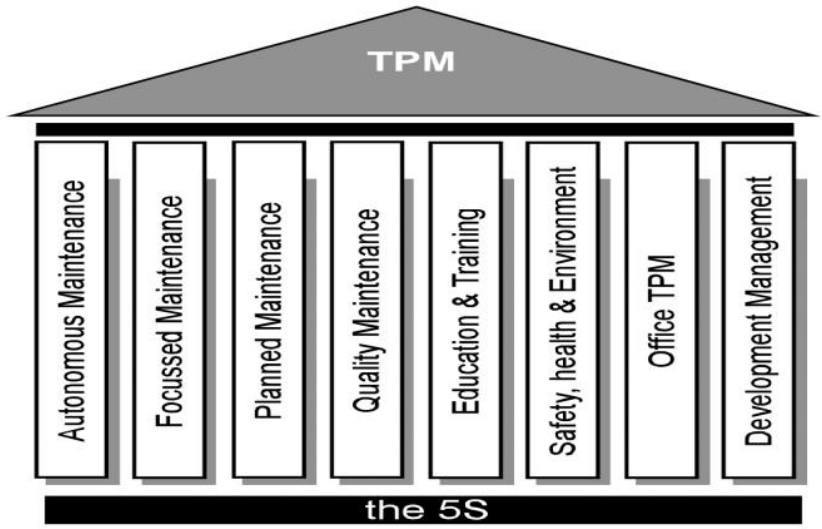

Fig 4 Eight pillars approach for TPM implementation [69].

\section{MAYNARD OPERATION SEQUENCE TECHNIQUE}

Dividing the operations into basic motions is developed in 1948 as Methods Time Measurement (MTM) for determining standard activity time [71]. Nature of MTM leads to disadvantages such us the tediousness of the work, the handling of a huge amount of detailed data during their application. [71-73]. To overcome this drawbacks H.B. Maynard and Company In in 1960s proposed MOST in literature. Maynard Operation Sequence Technique (MOST) is a way of examining the operations performing through various methods, steps and sequences in terms of time. MOST is one of the lean tool that can identify and eliminate the non-value added activities and bottlenecks workstations as described in Table 9. In 1970s finally, Clerical MOST, modified form of basic MOST is used to perform clerical and administrative work in the company. MOST can play a vital role that a company needs to reduce or eliminate the idle and/or down time, betterment of working methods, standardize the time and enhance the overall capacity planning and allows both repetitive and non-repetitive work for manufacturing with ease and accuracy [74]. It is combined study of work study, method study and work measurement and measures every minute spent on task as well as makes an analysis of work cost effective, practical and manageable [73-75]. MOST is a predetermined motion time system that is used in industrial settings to set the standard time in which a worker should perform a task. To calculate this, a task is broken down into individual motion elements, and each is assigned a numerical time value in units known as time measurement units, or TMUs, where 100,000 TMUs is equivalent to 1 hour. For obtaining standard time, motion elements and allowances are added [74].

To reduce the workers fatigue and to increase the accuracy and cost effectiveness of work MOST is implemented for identification and elimination of Non-value added activities, as a result $18 \%$ of working time is saved and defined a new set of reduced standard time [77]. Patil et al. [78] used MOST method for major time reduction in manufacturing of products and 60-65\% non-machining time reduction is achieved. Author also stated that, by this method it is possible to get production time of the products before its actual manufacturing starts. MOST is implemented in manufacturing process of Diesel Engine, to obtain standard time and to increase productivity for any enterprise, work study is the most effective tool [79]. Productivity is improved significantly in a small Indian industry by the application of MOST [80]. By the implementation of Single Minute Exchange of Dies through MOST, tool changeover time is reduced for Legrand (India) Pvt. Ltd., Jalgaon [77]. He proposed that by further applying MOST methods the tool changeover time will reduced to single digit. The integration of MOST with Ergonomics study helps to minimize the standard time of activities and fatigue of workers is reduced, resulting in gaining workforces a better environment and consequently the rate of productivity is increased [81]. By analyzing the case of sewing section in a garment industry, after applying MOST technique the total activity of same t-shirt which was taking a time of 139 seconds, takes on 109 seconds which means almost 40 seconds is reduced. It is also found out that bottleneck time is also reduced by the application of MOST from 48 seconds to 18 seconds [13]. Mishra et al. [82] carried out a case study on MOST and Traditional time study for fitment of particular parts at M/S Adithya Automotive Application Pvt. Ltd. and assembly line-3 at Tata Motors Ltd. Lucknow, results were total time decrease of $16.8 \%$ in first case and $32.2 \%$ decrease in second case. From this analysis author states that MOST has a clear advantage on Traditional time study and higher productivity. Cohen et al. [83] implemented MOST procedures for developing an auto speech recognition system, Talk MOST system, useful and represent as a great tool that reduce the analysis time and ease the establishment of time standards. Through computerization of data collection and the analysis procedure, the competence of proceeding with MOST becomes easier, reliable and faster, for standardizing the process of manufacturing in two industries [74]. Thus, it is a powerful analytical tool that helps to increase productivity, improve methods, facilitate planning, establish workloads, estimate labor costs, improve safety and maximize resources described in table 10.

Table no. 9 Maynard Operation Sequence Technique

\begin{tabular}{|c|c|c|}
\hline Author & Methodology & Results \\
\hline $\begin{array}{l}\text { Jain et al. (2014) } \\
{[76]}\end{array}$ & $\begin{array}{l}\text { MOST and time study is } \\
\text { conducted for analyzing } \\
\text { the labour resources } \\
\text { used and minimize or } \\
\text { reduce them. }\end{array}$ & $\begin{array}{l}\text { At assembly line of } \\
\text { product the time } \\
\text { decrement showed is } \\
2.72 \% \text { after successful } \\
\text { implementation of MOST. } \\
\text { Labour improvement takes } \\
\text { place from } 4 \text { workers to } 1 \\
\text { worker. }\end{array}$ \\
\hline $\begin{array}{l}\text { Tuan et al. } \\
(2014) \text { [74] }\end{array}$ & $\begin{array}{l}\text { MOST is implemented } \\
\text { for improving the } \\
\text { productivity undertaken } \\
\text { by auto firm. }\end{array}$ & $\begin{array}{l}\text { By assessment of } \\
\text { increment of production } \\
\text { rate and amount of } \\
\text { investment, working tools } \\
\text { productivity is increased } \\
\text { by modified methods. }\end{array}$ \\
\hline $\begin{array}{l}\text { Patel and Tomar } \\
\text { (2017) [84] }\end{array}$ & $\begin{array}{l}\text { MOST technique is } \\
\text { applied for production } \\
\text { and assembling in } \\
\text { automation sector. }\end{array}$ & $\begin{array}{ll}\text { - } & \text { Reduced cost } \\
\text { - } & \text { Accuracy } \\
& \text { within } \pm 5 \% \\
& \text { with a } \\
95 \% \text { confidence } \\
\text { - level. } \\
\text { Improve } \\
\text { - } \quad \text { productivity. } \\
\text { Streamline } \\
\text { operations. }\end{array}$ \\
\hline
\end{tabular}




\begin{tabular}{|c|c|c|}
\hline $\begin{array}{lr}\text { Meshram } & \text { and } \\
\text { Marre } & \text { (2017) } \\
{[85]} & \end{array}$ & $\begin{array}{l}\text { By applying basic } \\
\text { MOST technique, to } \\
\text { analyze the Nonvalue } \\
\text { added activities and } \\
\text { reduce and eliminate } \\
\text { them }\end{array}$ & $\begin{array}{l}\text { Reduced } 18.1 \% \text { or } 5.78 \\
\text { min of the total activity. } \\
\text { MOST technique gives } \\
\text { more accuracy than time } \\
\text { study method. }\end{array}$ \\
\hline $\begin{array}{l}\text { Rahman et al. } \\
(2018) \text { [13] }\end{array}$ & $\begin{array}{l}\text { MOST technique is } \\
\text { implemented for } \\
\text { identifying and } \\
\text { minimizing added } \\
\text { bottlenecks and } \\
\text { nonvalue andion } \\
\text { activities of production } \\
\text { line thus setting standard } \\
\text { time. }\end{array}$ & $\begin{array}{l}\text { Bottleneck time reduced } \\
\text { from } 139 \text { seconds to } 109 \\
\text { seconds, } 40 \text { seconds is } \\
\text { decreased by improving } \\
\text { the method of working } \\
\text { motion. }\end{array}$ \\
\hline $\begin{array}{l}\text { Mishra et } \\
(2014) \text { [82] }\end{array}$ & $\begin{array}{l}\text { Comparative case } \\
\text { studies of MOST and } \\
\text { Time study is calculated } \\
\text { in two automotive firm } \\
\text { for fitment of particular } \\
\text { parts in Lucknow. }\end{array}$ & $\begin{array}{l}\text { A Total time decrease is } \\
16.8 \% \text { in MOST case and } \\
32.2 \% \text { decrease in second } \\
\text { time study case. MOST } \\
\text { gives a clear advantage } \\
\text { over traditional time study } \\
\text { and yields higher } \\
\text { productivity. }\end{array}$ \\
\hline
\end{tabular}

\section{CONLUSION}

In this paper, an attempt is made to review and identify different lean manufacturing tools that helps for the improvement of productivity. The types of lean manufacturing tools studied as: Value Stream Mapping (VSM), Single Minute Exchange of Dies (SMED), Overall Equipment Efficiency (OEE), Cellular Manufacturing (CM), Assembly Line Balancing (ALB), Kanban system, Total Productive Maintenance (TPM), and Maynard Operation Sequence Technique (MOST).The implementation of lean manufacturing tools is low cost solution and needs integration of lean elements with proper sequence to achieve productivity and profitability in the industry. Lean tools helps in achieving reliable deliveries, enhanced safety, motivating working environments, fewer breakdowns. It is like the boon of nectar provided to the world wide organizations for betterment of their own prospects. The present survey definitely helps the industries, SME's for choosing one of the lean tools that will suit it for employing enhanced results with low costs. In the world of Industry 4.0, Lean manufacturing tools can provide the best solution to the expanding need of higher productivity.

\section{REFERENCES}

[1] J. Womack, D. Jones, D. Roos, Machine that changed the world. Simon and Schuster; 1990.

[2] J. P. Womack, D, T, Jones, Lean Consumption. Harvard Business Review, (2005).

[3] N. Piercy, N. Rich, Lean transformation in the pure service environment the case of the call service centre. International journal of operations \& production management, 29(1), (2009) 54-76.

[4] R. Sundar, A.N. Balaji, R.M.S. Kumar, Procedia Eng., vol. 97, (2014) $1875-1885$

[5] M. Kumar, R. Vaishya, Parag, Real-Time Monitoring System to Lean Manufacturing. Procedia Manufacturing, 20, (2018) 135-140

[6] O. Babalola, E. O. Ibem I. C. Ezema, Implementation of lean practices in the construction industry: A systematic review, Building and Environment (2018)

[7] C. Roriz, E. Nunes, and S. Sousa, "Application of Lean Production Principles and Tools for Quality Improvement of Production Processes in a Carton Company, Procedia Manuf., vol. 11, (2017) 1069-1076.

[8] G. D'Antonio, J. S. Bedolla, P. Chiabert, A Novel Methodology to Integrate Manufacturing Execution Systems with the Lean Manufacturing Approach. Procedia Manufacturing, 11, (2017) 22432251.
[9] F. H. Abernathy, J. T. Dunlop, J. H. Hammond, D. Weil, Retailing and supply chains in the information age. Technol Soc (2000) 5-31

[10] L. Foulloy, V. Clivillé, L. Berrah, A fuzzy temporal approach to the Overall Equipment Effectiveness measurement. Computers \& Industrial Engineering (2018).

[11] S. Angra, R. Sehgal, S. Noori,. Cellular manufacturing-A time-based analysis to the layout problem. International Journal of Production Economics, 112(1), (2008) 427-438

[12] N. A. A. Rahman, S. M. Sharif, M. M. Esa, Lean Manufacturing Case Study with Kanban System Implementation. Procedia Economics and Finance, 7, (2013) 174-180.

[13] M.S.Rahman, R.Karim, J.Mollah, S.Miah, Implementation of maynard operation sequence technique (most) to improve productivity and workflow - a case study, Journal of Emerging Technologies and Innovative Research, Volume 5, Issue 6, (2018) 269-278

[14] M. Rother, J. Shook, Learning to see: value stream mapping to add value and eliminate muda. Lean Enterprise Institute (2003).

[15] P. P. Sheth, Value Stream Mapping: A Case Study of Automotive Industry, Ijret (2014), 2321-7308.

[16] M. Rehab, Dynamic Lean Assessment for Takt Time Implementation, Procedia CRIP 17 (2014), 577-581

[17] M Al-Odeh, A. McLeod, M. A. Badar, M. Affan, Value Stream Mapping: Recreating an Industrial Environment in an Educational Setting. Proceedings of The 2014 IAJC/ISAM Joint International Conference (2014).

[18] A. Fawaz, A. Malek, J. Rajgopal, Analyzing the benefits of lean manufacturing and value stream mapping via simulation: A process sector case study, Int. J. Production Economics 107 (2007) 223-236.

[19] T. McDonald, V. Aken, A. F. Rentes, Utilizing simulation to enhance value stream mapping: a manufacturing, case application. International Journal of Logistics, Research and Applications 5 (2) (2002) 213-232.

[20] H. Singh, A. Bahl, A. Kumar, M. G. Singh, Materials and Information Flow Analysis and Optimization of Manufacturing Processes in MSMEs by the Application of Value Stream Mapping (VSM) Technique. Materials Today: Proceedings, 5(14), (2018) 28420-28426.

[21] D. Stadnicka, R. M.C. Ratnayake, Minimization of service disturbance: VSM based case study in telecommunication industry. IFACPapersOnLine, 49(12), (2016) 255-260.

[22] D. Stadnicka, R. M. C. Ratnayake, Enhancing Aircraft Maintenance Services: A VSM Based Case Study. Procedia Engineering, 182, (2017) 665-672.

[23] A. Brown, J. Amundson, F. Badurdeen, Sustainable value stream mapping (Sus-VSM) in different manufacturing system configurations: application case studies. Journal of Cleaner Production, 85, (2005) 164 179.

[24] A. Espinosa, E. Reficco, A. Martínez, D. Guzmán, A methodology for supporting strategy implementation based on the VSM: A case study in a Latin-American multi-national. European Journal of Operational Research, 240(1), (2015) 202-212

[25] S. Shingo, A revolution in manufacturing: the SMED system Productivity Press (1985)

[26] G. Gest, S. J. Culley, R. I. McIntosh, A. R. Mileham, G. W. Owen, Review of fast tool change systems. Computer Integrated Manufacturing Systems 8, (1995) 205-210.

[27] E. A. Coimbra, Total Flow Management: Achieving Excellence with Kaizen and Lean Supply Chains. Kaizen Institute (2009).

[28] P. G. Ferradás and K. Salonitis, Improving Changeover Time: A Tailored SMED Approach for Welding Cells, Procedia CIRP, vol. 7, (2013) 598-603

[29] H. D. Sherali, D.V. Goubergen, H.V. Landeghem, A quantitative approach for scheduling activities to reduce set-up in multiple machine lines, European Journal of Operational Research, 187 (2008) 1224-1237.

[30] C. Rosa, F. J. G. Silva, L. P. Ferreira, and R. Campilho, SMED methodology: The reduction of setup times for Steel Wire-Rope assembly lines in the automotive industry, Procedia Manuf., vol. 13, (2017) 1034-1042

[31] M. Martins, R. Godina, C. Pimentel, F. J. G. Silva, J. C.O. Matias, A Practical Study of the Application of SMED to Electron-beam Machining in Automotive Industry. Procedia Manufacturing, 17, (2018) 647-654.

[32] E. Sousa, F. J. G. Silva, L. P. Ferreira, M. T. Pereira, R. Gouveia, R. P. Silva, Applying SMED methodology in cork stoppers production Procedia Manufacturing, 17, (2018) 611-622.

[33] A. A. Karam, M. Liviu, V. Cristina, H. Radu, The contribution of lean manufacturing tools to changeover time decrease in the pharmaceutical 
industry. A SMED project. Procedia Manufacturing, 22, (2018) 886892

[34] M. Brito, A. L. Ramos, P. Carneiro, and M. A. Gonçalves, Combining SMED methodology and ergonomics for reduction of setup in a turning production area, Procedia Manuf., vol. 13, (2017) 1112-1119.

[35] R. Godina,C. Pimentel, F. J. G. Silva, J. C. O. Matias, A Structural Literature Review of the Single Minute Exchange of Die: The Latest Trends. Procedia Manufacturing, 17, (2018) 783-790.

[36] A. Simões and A. Tenera, Improving setup time in a Press Line Application of the SMED methodology, IFAC Proc. Vol., vol. 43, no. 17, (2010) 297-302.

[37] H. R. Steinbacher, N. L. Steinbacher, TPM for America. Portland, Oregon: Productivity Press (1993)

[38] D. Hogfeldt, Plant efficiency: A value stream mapping and overall equipment effectiveness study. Lulea University of Technology (2005).

[39] Y. J. Ki, D. T. Phillips, Operational efficiency and effectiveness measurement. International Journal of Operations \& Production Management, (2001) 1404-1416.

[40] T. Dunn, OEE effectiveness. In Manufacturing flexible packaging: Materials, machinery, and techniques, William Andrew Publishing, Oxford, (2014) 77-85.

[41] C. Andersson, M. Bellgran, On the complexity of using performance measures: Enhancing sustained production improvement capability by combining OEE and productivity. Journal of Manufacturing Systems, (2015) 144-154

[42] S. Nakajima, Introduction to Total Productive Maintenance, Japan InPlant Maintenance, Productivity Press, (1988)

[43] A. P. Puvanasvaran, C.Z. Mei, V.A. Alagendran, Overall Equipment Efficiency Improvement Using Time Study in an Aerospace Industry, The Malaysian International Tribology Conference (2013).

[44] R. Hedman, M. Subramaniyan, P. Almström, Analysis of critical factors for automatic measurement of OEE. Procedia CIRP, 57, (2016) 128-133.

[45] M. K. Kumar, A. J. Rajan, R.K.B. Navas, S.S. Rubinson, Application of lean manufacturing in mass production system: a case study in Indian manufacturing unit. Proceedings of the international conference on industrial engineering and engineering management IEEE; (2014).

[46] G. C. Onwubolu, Redesigning jobshops to cellular manufacturing systems.Integrated Manufacturing Systems, 9(6), (1988) 377-382.

[47] U. Wemmerlöv, N. L. Hyer, Cellular manufacturing in the US industry: a survey of users. The international journal of production research,27(9), (1989) $1511-1530$

[48] J. Drolet, G. Abdulnour, M. Rheault, The cellular manufacturing evolution. Computers \& industrial engineering, 31(1), (1996) 139-142.

[49] I. M. Eliguzel, E. Ozceylan, Comparison of Different Clustering Methods for Cellular Manufacturing: A Case of Gym Centre. Procedia Computer Science, 158, (2019) 1-8.

[50] Yin, Yong, and K. Yasuda, Similarity Coefficient Methods Applied to the Cell Formation Problem: A Comparative Investigation, Computers and Industrial Engineering 48(3): (2005) 471-89.

[51] K. Das, R.S. Lashkari, S. Sengupta, Reliability consideration in the design and analysis of cellular manufacturing systems, Int. J. Production Economics 105 (2007) 243-262.

[52] J. Balakrishnan, C. H. Cheng, Multi-period planning and uncertainty issues in cellular manufacturing: A review and future directions. European Journal of Operational Research, 177(1), (2007) 281-309.

[53] N. C. Suresh, J. R. Meredith, Achieving factory automation through group technology principles. Journal of Operations Management,5(2), (1985) 151-167.

[54] P. Gu and A. Monid, Design of cellular manufacturing systems - an industrial case study, Robotics \& Computer-Inte\#rated Manufacturino, Vol. 10, No. 1/2, (1993) 147-151

[55] N. T. Lam, L. M. Toi, V. T. T. Tuyen, D. N. Hien, Lean Line Balancing for an Electronics Assembly Line. Procedia CIRP, 40, (2016) 437-442.

[56] J. Gao, L. Sun, L. Wang, M. Gen, An efficient approach for type II robotic assembly line balancing problems, Computers \& Industrial Engineering Vol.56, (2009) 1065-1080.

[57] A.F.H. Fansuri, IOP Conf. Ser.: Mater. Sci. Eng. 409012015

[58] T. C. Lopes, C. G. S. Sikora, R. G. Molina, D. Schibelbain, L. C. A. Rodrigues, L. Magatao, Balancing a Robotic Spot Welding Manufacturing Line: an Industrial Case Study, European Journal of Operational Research (2017)

[59] M. G. Surendra, A. Y. Yousef, F. P. Ronal, Flexible Kanban system. International Journal of Operations and Production Management. Vol. 19, No. 10, (1999) 1065-1093.
[60] F.T.T. Chan, Effect of kanban size on just-in-time manufacturing systems. Journal of Materials Processing Technology, (2001) 146-160.

[61] U. S. Karmarker, S. Kekre, Batching policy in Kanban system, J manufacturing systems, (1989), 317-328

62] B. S. M. Domingo, R. B. Ribeiro, J. G. M. Barros, A. H. A. Júnior, F. S. Sabbadini, Process Improvement and Reorganization of Kanban Inventory in an Industry of Machinery and Equipment: A Case Study, Journal of Mechanical Engineering and Automation, (2014), 49-54

[63] A. Naufal, A. Jaffar, N. Yusoff, N. Hayati, Development of Kanban System at Local Manufacturing Company in Malaysia-Case Study. Procedia Engineering, 41, (2012) 1721-1726.

[64] S. Nakajima, Introduction to TPM: Total productive maintenance. Cambridge: Productivity Press (1984)

[65] J. Oliveira, J. C. Sá, and A. Fernandes, Continuous improvement through 'Lean Tools': An application in a mechanical company, Procedia Manuf., vol. 13, (2017) 1082-1089

[66] Y. Ngadiman, Dr. B. Hussin, Dr. I. A. Majid, Study of total productive maintenance implementation in manufacturing industry for generating greater profits, Proceedings International Conference of Technology Management, Business and Entrepreneurship, (2012) 157-173

[67] V. Pascal, A. Toufik, A. Manuel, D. Florent, K. Frédéric, Improvement indicators for Total Productive Maintenance policy. Control Engineering Practice, (2019) 86-96.

[68] C. S. Sethia, Prof. P. N. Shende, S. S. Dange, A Case Study on Total Productive Maintenance in Rolling Mill, Journal of Emerging Technologies and Innovative Research, Volume 1 Issue 5, (2014) 283 289

[69] J. M. Simões, C. F. Gomes, M. M. Yasin, A literature review of maintenance performance measurement: A conceptual framework and directions for future research. Journal of Quality in Maintenance Engineering, (2011) 116-137.

[70] H. G. Hegde, N.S. Mahesh, K. Doss, Overall Equipment efficiency improvement by TPM and $5 \mathrm{~s}$ techniques' in CNC machine shop, SASTECH, vol.8, (2009)

[71] A. M. Genaidy, A. Mital, M. Obeidat, The validity of predetermined motion time systems in setting production standards for industrial tasks, International Journal of Industrial Ergonomics, vol.3, no.3, (1989) 249 263 .

[72] A. M. Genaidy, A. Agrawal, A. Mital, Computerized predetermined motion-time systems in manufacturing industries, Computers \& Industrial Engineering, vol.18, no.4, (1990) 571-584

[73] L. Ma, W. Zhang, H. Fu, Y. Guo, D. Chablat, F. Bennis, ..., N. Fugiwara A framework for interactive work design based on motion tracking, simulation, and analysis, Human Factors and Ergonomics in Manufacturing \& Service Industries, vol.20, no.4, (2010.)339-352,

[74] S. T. Tuan, Improvement of Workflow and Productivity through Application of Maynard Operation Sequence Technique (MOST) Proceedings of the 2014 International Conference on Industrial Engineering and Operations Management Bali, Indonesia, January 7 - 9 , (2014).

[75] G. Salvendy, Handbook of industrial engineering. Third edition. Wiley Interscience, John Wiley \& Sons, (2001).

[76] R. Jain, S. Gupta, G. S. Dangayach, Optimization of Labour Productivity Using MOST Technique, International Journal of Productivity and Quality Management, (2016) 485-510

[77] R. M. Belokar, V. Kumar, S. S. Kharb, An application of value stream mapping in automotive industry: a case study. International Journal of Innovative Technology and Exploring Engineering, 1(2), (2012) 152157

[78] S. S. Patil, B. M. Shinde, R. S. Katikar, M. V. Kavade, MOST an advance technique to improve productivity, National Conference on recent trends in CAD/CAM/CAE(NCRTC 2004), 21-23 June 2004,

[79] A. P. Vekariya, Productivity Improvement Of Manufacturing Process Of Diesel Engine By Time And Motion Study Method (MOST Technique), IJAERD, Volume 2, Issue 6, (2015) 577-584.

[80] M. P. K. Gupta, M. S. S. Chandrawat, To improve work force productivity in a medium size manufacturing enterprise by MOST Technique, IOSR Journal of Engineering (IOSRJEN), Vol. 2, no.10, (2012) 08-15

[81] M. Jamil, M.Gupta, A. Saxena, V. Agnihotri, Optimization of Productivity by Work Force Management through Ergonomics and Standardization of Process Activities using M.O.S.T Analysis, Global Journal of Researches in Engineering (2013).

[82] A. Mishra, V. Agnihotri, D. V. Mahindru, Application of Maynard Operation Sequence Technique (M.O.S.T) at Tata Motors and Adithya 
Automotive Application Pvt Ltd. Lucknow for Enhancement of Productivity-A Case Study, Global Journal of Researches in Engineering: B Automotive Engineering, Volume 14, Issue 2 (2014)

[83] Y. Cohen, B. Bidanda, R. E. Billo, Accelerating the generation of work measurement standards through automatic speech recognition: a laboratory study, International journal of production research, vol.36, no.10, (1998) 2701-2715,

[84] D. Patel, P. Tomar, A Review on Optimization in Total Operation Time Through Maynard Operation Sequence Technique, International Journal of Science Technology \& Engineering, Volume 3, Issue 09, (2017) 13 16

[85] P. R. Meshram, R. Marre, Process Optimization by Elimination of NVA Activities Through 'Most' Technique, International Journal of Mechanical and Production Engineering (IJMPE) , 6-10, Volume5,Issue-11, (2017). 